\title{
Beyond the state of play: Establishing a duty of non-State armed groups to provide reparations
}

\section{Olivia Herman*}

Olivia Herman holds a PhD in Law from the KU Leuven, Belgium. She is an affiliated senior researcher at the Leuven Centre for Global Governance Studies - Institute for International Law.

\begin{abstract}
This article examines whether and how non-State armed groups, as distinct entities, might be required to provide reparations for their violations of international humanitarian law. It shows that the possibility of holding armed groups to reparations is marked by uncertainty in international law. This complex question calls for clarification. In building on these observations, the article explores how the duty to provide reparations by armed groups could be operationalized as a matter of lex ferenda. This exercise involves examining how such a duty could be conceptualized and put into practice. From this discussion, a multi-faceted proposal emerges, which draws upon existing approaches in international law and responds to the particular challenges presented by armed groups. The article ends by considering the implications of the proposal.
\end{abstract}

* This article is based on the author's PhD dissertation entitled "Righting Wrongs: Non-State Armed Groups and Reparations for Victims of Armed Conflict, with a Case Study of Colombia". The author would like to thank Dr Laura Înigo Álvarez for her comments on an earlier draft of the article. The research was carried out with support from the Research Foundation-Flanders (FWO).

(c) The Author(s), 2021. Published by Cambridge University Press on behalf of the ICRC. This is an Open Access article, distributed under the terms of the Creative Commons Attribution licence (http:// creativecommons org/licenses/by/4.0/), which permits unrestricted re-use, distribution, and reproduction Downloaded from https://Www. cambricge.org/core. 'KU Leu en Libraries, on 07 Oct 2021 at 10:25:08, subject to the Cambridge Core terms of use, 
Keywords: non-State armed groups, reparations, international responsibility, victims, non-international armed conflict, international humanitarian law.

\section{Introduction}

It is no secret that non-international armed conflicts involving armed groups have become the dominant form of armed conflict, while inter-State conflict has become a rather exceptional occurrence. ${ }^{1}$ In this context, the International Committee of the Red Cross (ICRC) identified, in its 2019 Challenges report, the "proliferation of non-State armed groups" as a central feature of "the changing geopolitical landscape of the last decade". 2 The realities of these present-day armed conflicts, such as the protracted conflicts in the Central African Republic, Syria and Colombia, demonstrate the detrimental impacts that they can have in terms of human suffering, damage to property and displacement. ${ }^{3}$ It is clear that in such contexts harms have resulted from the wrongful acts committed by both States and non-State armed groups, which are parties to non-international armed conflicts. ${ }^{4}$

There has been gradual growth in awareness and recognition of the plight of victims of armed conflict and of the need to provide reparations for the harmful consequences that they have endured following violations of international law. ${ }^{5}$ Reparation for wrongs developed historically as a means of settling disputes between offenders and victims; it is generally understood as involving the obligation of a responsible person, or entity, to redress the injury caused as a

1 This article deals with any armed group which seeks to obtain certain political, social or other objectives as a party to a non-international armed conflict, and which operates independently from States, as denoted in the adopted term "non-State armed group". ICRC, The Roots of Restraint in War, Geneva, December 2018, p. 13; Therése Pettersson, Stina Högbladh and Magnus Öberg, "Organized Violence, 1989-2018 and Peace Agreements", Journal of Peace Research, Vol. 56, No. 4, 2019.

2 ICRC, International Humanitarian Law and the Challenges of Contemporary Armed Conflicts, Geneva, October 2019, available at: https://shop.icrc.org/international-humanitarian-law-and-the-challenges-ofcontemporary-armed-conflicts-recommitting-to-protection-in-armed-conflict-on-the-70th-anniversaryof-the-geneva-conventions-pdf-en, p. 50 (all internet references were accessed in August 2021).

3 Centro Nacional de Memoria Histórica, ;Basta Ya! Colombia: Memories of War and Dignity, Bogotá, June 2016, available at: http://centrodememoriahistorica.gov.co/descargas/informes2016/basta-ya-ingles/ BASTA-YA-ingles.pdf; International Crisis Group, Colombia's Armed Groups Battle for the Spoils of Peace, Brussels, October 2017, available at: https://www.crisisgroup.org/latin-america-caribbean/andes/ colombia/63-colombias-armed-groups-battle-spoils-peace; Human Rights Watch, Central African Republic: Armed Group Kills 46 Civilians, Nairobi, July 2019, available at: https://www.hrw.org/news/ 2019/07/18/central-african-republic-armed-group-kills-46-civilians; Amnesty International, "Nowhere Is Safe for Us": Unlawful Attacks and Mass Displacement in North-West Syria, London, May 2020, available at: https://www.amnesty.org/en/documents/mde24/2089/2020/en/.

4 Annyssa Bellal, "Welcome on Board: Improving Respect for International Humanitarian Law Through the Engagement of Armed Non-State Actors", in Terry D. Gill, Tim McCormack, Robin Geis, Heike Krieger and Christophe Paulussen (eds), Yearbook of International Humanitarian Law, Vol. 19, T.M.C. Asser Press, The Hague, 2016, pp. 39-40; Report of the Secretary-General on the Protection of Civilians in Armed Conflict, UN Doc. S/2020/366, 6 May 2020.

5 Theo van Boven, "Reparative Justice - Focus on Victims", Netherlands Quarterly of Human Rights, Vol. 25, No. 4, 2007; Christine Evans, The Right to Reparation in International Law for Victims of Armed Conflict, Cambridge University Press, Cambridge, 2012, pp. 1-2 and 233-236. 
result of an unlawful act. ${ }^{6}$ Besides constituting a fundamental legal principle in domestic legal systems, reparation has also gained a firm basis in international law: first, as an inter-State mechanism and, later, as a broader responsibility mechanism also addressed to certain non-State actors, particularly individuals and international organizations. ${ }^{7}$ Under international law, the duty to repair is one of the legal consequences which arises from the commission of an internationally wrongful act by a responsible actor. ${ }^{8}$ Reparations generally seek to restore the situation that existed before the wrong occurred, so-called full reparation or restitutio in integrum, by way of a different range of forms, including restitution, compensation, rehabilitation, satisfaction and guarantees of non-repetition. ${ }^{9}$

The duty of wrongdoers to provide reparation has been recognized as an important justice and accountability measure for victims of armed conflict or, in the words of Judge Cançado Trindade, as "an imperative of justice". ${ }^{10}$ This notion is also reflected in the United Nations (UN) Basic Principles and Guidelines on the Right to a Remedy and Reparation for Victims of Gross Violations of International Human Rights Law and Serious Violations of International Humanitarian Law (Basic Principles), which hold that "reparation is intended to promote justice by redressing gross violations of international human rights law or serious violations of international humanitarian law", and more broadly in the field of transitional justice. ${ }^{11}$ Within this context, the International Criminal Court held that one of the purposes of reparations, besides redressing the harm, is that they enable the Court to ensure that those responsible for

6 M. Cherif Bassiouni, “International Recognition of Victims' Rights”, Human Rights Law Review, Vol. 6, No. 2, 2006, p. 207; Pablo de Greiff, "Justice and Reparations", in Pablo de Greiff (ed.), The Handbook of Reparations, Oxford University Press, Oxford, 2006, p. 452; Liesbeth Zegveld, "Victims' Reparation Claims and International Criminal Courts: Incompatible Values?", Journal of International Criminal Justice, Vol. 8, No. 1, 2010, p. 81.

7 Rome Statute of the International Criminal Court, UN Doc. A/CONF.183/9, 17 July 1998 (entered into force 1 July 2002), Art. 75; Permanent Court of International Justice (PCI), Factory at Chorzów (Germany v. Poland), Series A, No. 17, Judgment (Merits), 13 September 1928, p. 29; International Law Commission (ILC), Articles on Responsibility of States for Internationally Wrongful Acts, with Commentaries, Yearbook of the International Law Commission, Vol. II, Part Two, 2001 (ARS), Art. 31; ILC, Articles on the Responsibility of International Organizations, with Commentaries, Yearbook of the International Law Commission, Vol. II, Part Two, 2011 (ARIO), Art. 31; Naomi Roht-Arriaza, "Reparations Decisions and Dilemmas", Hastings International and Comparative Law Review, Vol. 27, No. 2, 2004, p. 157; M. C. Bassiouni, above note 6, pp. 206-207.

8 International Criminal Court (ICC), The Prosecutor v. Thomas Lubanga Dyilo, Case No. ICC-01/04-01/ 06-3129-AnxA, Order for Reparations (Appeals Chamber), 3 March 2015, para. 2; ARS, above note 7, Arts 28 and 31; ARIO, above note 7, Arts 28 and 31.

9 UNGA Res. 60/147, 21 March 2006, paras 18-23. Compare with the more restricted conceptualization in ARS, above note 7, Arts 34-37. PCIJ, Factory at Chorzów Case (Merits), above note 7, p. 47; InterAmerican Court of Human Rights, Velásquez Rodríguez v. Honduras, Series C, No. 4, Judgment (Merits), 29 July 1988, para. 166; International Court of Justice, Armed Activities on the Territory of the Congo (Democratic Republic of the Congo v. Uganda), Judgment, ICJ Reports 2005, para. 259.

10 International Court of Justice, Ahmadou Sadio Diallo (Republic of Guinea v. Democratic Republic of the Congo), Judgment, Separate Opinion of Judge Cançado Trindade, ICJ Reports 2012, paras 32-34, 40 and 97.

11 UNGA Res. 60/147, above note 9, para. 15; Promotion of Truth, Justice, Reparation and Guarantees of Non-Recurrence - Note by the Secretary-General, UN Doc. A/69/518, 14 October 2014, para. 11. 
serious crimes account for their acts. ${ }^{12}$ Importantly, reparations are one of the only measures which are specifically designed to benefit the victims of armed conflict directly, while acknowledging their suffering and needs, and attempting to address the harms that they have endured. ${ }^{13}$ In other words, "reparations constitute an effort that is explicitly and primarily carried out on behalf of victims" and, in doing so, they go beyond the narrow focus of criminal prosecution. 14

The recognition that non-State armed groups have become one of the main protagonists in present-day armed conflicts, and that they can cause significant harm in the societies in which they operate as a result of their violations of international humanitarian law, calls for holding these groups responsible vis-àvis their victims. This call is reinforced by the significance of this measure in countering impunity. More specifically, it raises the question as to whether, like the States that are party to these conflicts, armed groups should also hold a duty under international law to make reparation for the harms they have inflicted on their victims. ${ }^{15}$ However, as the UN Special Rapporteur on extrajudicial, summary or arbitrary executions recently concluded, and as will be discussed in further detail, "the current legal framework to hold them accountable has unacceptably large deficits with regard to access to justice, remedies, and reparations". 16

In tackling this question, the article begins by examining, in the next section, the state of play of non-State armed groups' possible duty of reparation under current international humanitarian law. The remainder of this article explores how such a duty could be operationalized as part of a future responsibility regime, which involves determining how this duty could be conceptualized and put into practice. In doing so, it makes a significant contribution to the scholarly debate by clarifying some of the rules and principles that could govern the content of armed groups' international responsibility.

The discussion will first argue that the possible duty of non-State armed groups to provide reparations is marked by uncertainty in international law and needs clarification. The second part of the article will present a multi-faceted proposal on how such a duty for armed groups could be operationalized as a matter of lex ferenda, by arguing for the introduction of a cascading regime of responsibility for reparation and an actor-specific approach. The analysis draws

12 ICC, Lubanga, above note 8, para. 2.

13 Lisa Magarrell, Reparations in Theory and Practice, International Center for Transitional Justice, New York, 2007, available at: https://ictj.org/sites/default/files/ICTJ-Global-Reparations-Practice-2007English.pdf, p. 2.

14 Pablo de Greiff, "Repairing the Past: Compensation for Victims of Human Rights Violations", in Pablo de Greiff (ed.), The Handbook of Reparations, Oxford University Press, Oxford, 2006, p. 2; Ron Dudai, "Closing the Gap: Symbolic Reparations and Armed Groups", International Review of the Red Cross, Vol. 93, No. 883, 2011, p. 787; Note by the Secretary-General, above note 11, para. 10.

15 Laura Íñigo Álvarez, "The Obligation to Provide Reparations by Armed Groups: A Norm under Customary International Law?", Netherlands International Law Review, Vol. 67, No. 3, 2020, p. 428.

16 Report of the Special Rapporteur on Extrajudicial, Summary or Arbitrary Executions on Armed Non-State Actors: The Protection of the Right to Life, UN Doc. A/HRC/38/44, 5 June 2018, para. 21. 
from existing approaches to reparations in the law of international responsibility and from examples in practice. Simultaneously, the particularities that are presented by these armed actors are taken into account, including some of the responses that have developed thereto under international humanitarian law. To conclude, the implications of the proposal will be considered.

\section{Non-State armed groups and reparations under international humanitarian law}

It would appear logical that non-State armed groups, as such, should incur international responsibility, and a resulting duty of reparation, where they violate their well-established primary obligations under international humanitarian law. Yet, this question is far from being settled. Indeed, there is, at present, no treaty or legal instrument, nor any accompanying forum, that provides a normative and institutional framework to hold armed groups internationally responsible for their wrongful acts.

The ICRC Commentary of 2020 to Article 3 common to the four Geneva Conventions confirms that "[i]nternational law is unclear as to the responsibility of a non-State armed group, as an entity in itself, for acts committed by members of the group". ${ }^{17}$ Moreover, the ICRC Customary Law Study of 2005 recognizes that such international responsibility could at least be argued but, at the same time, indicates that it is particularly unclear to what extent armed groups are under a duty to make full reparation. ${ }^{18}$ This study makes further reference to the Articles on State Responsibility, drafted by the International Law Commission, whose Commentary leaves the possibility open that an armed group may itself be held responsible for breaches of humanitarian law by its forces. ${ }^{19}$ All in all, the international responsibility of armed groups is neither firmly affirmed nor is it rejected in the work of the ICRC and the International Law Commission, respectively.

The question of responsibility also remains controversial in legal scholarship. Some scholars argue that the international responsibility of non-State armed groups in international humanitarian law has been recognized, and that the contemporary debate should centre on issues such as attribution or content of responsibility. ${ }^{20}$ However, this position is far from universal, and the majority of scholars have been more careful in their assertions. Aside from arguing for the

17 ICRC, Commentary on the Third Geneva Convention, 2020, available at: https://ihl-databases.icrc.org/ihl/ full/GCIII-commentary, para. 931.

18 Jean-Marie Henckaerts and Louise Doswald-Beck (eds), Customary International Humanitarian Law, Vol. 1: Rules, Cambridge University Press, Cambridge, 2005 (ICRC Customary Law Study), available at: https://ihl-databases.icrc.org/customary-ihl/eng/docs/v1, pp. 536 and 550.

19 ARS, above note 7, ILC Commentary to Art. 10, p. 52, para. 16.

20 Liesbeth Zegveld, The Accountability of Armed Opposition Groups, Cambridge University Press, Cambridge, 2002, pp. 133-134; Marco Sassòli, “Taking Armed Groups Seriously: Ways to Improve Their Compliance with International Humanitarian Law", Journal of International Humanitarian Legal Studies, Vol. 1, No. 1, 2010, p. 47. See e.g. Report of the International Commission of Inquiry on 
responsibility of armed groups and identifying increased support for such a development, this latter group of scholars generally concludes that existing practice is too scarce to draw any definite conclusion on the matter. ${ }^{21}$

At best, the wrongful conduct of non-State armed groups has been dealt with through monitoring and sanctioning efforts by, for instance, the UN Security Council, commissions of inquiry and other fact-finding missions, while justice efforts have predominantly focused on holding individuals criminally responsible for the crimes committed on the occasion of their membership to such groups. ${ }^{22}$ From a reparative justice perspective, these initiatives remain unsatisfactory, since they do not provide an avenue for victims to claim reparations directly from responsible armed groups for the entire spectrum of violations and harms caused. ${ }^{23}$ Moreover, the existing regime of State responsibility does not remedy this situation in a satisfactory manner, since a State is in principle not responsible for the wrongs committed by non-State armed groups, unless the group is successful in establishing a new government or State. ${ }^{24}$ Yet, this leaves the responsibility of unsuccessful groups unaddressed.

This state of play sits in stark contrast with a fundamental principle of international law, in the words of the Permanent Court of International Justice: "it is a principle of international law, and even a general conception of law, that any breach of an engagement involves an obligation to make reparation". 25 Moreover, in contrast to armed groups, States, which are party to noninternational armed conflicts, hold a secondary obligation to make full reparation

Darfur, 25 January 2005, para. 175; Report of the Secretary-General's Panel of Experts on Accountability in Sri Lanka, 31 March 2011, para. 191.

21 Jann K. Kleffner, "The Collective Accountability of Organized Armed Groups for System Crimes", in Andre Nollkaemper and Harmen Gijsbrecht van der Wilt (eds), System Criminality in International Law, Cambridge University Press, Cambridge, 2009, pp. 255-256; Veronika Bílková, "Establishing Direct Responsibility of Armed Opposition Groups for Violations of International Humanitarian Law?", in Noemi Gal-Or, Cedric Ryngaert and Math Noortmann (eds), Responsibilities of the NonState Actor in Armed Conflict and the Market Place, Brill Nijhof, Leiden/Boston, 2015, pp. 276-277; Kirsten Schmalenbach, "International Responsibility for Humanitarian Law Violations by Armed Groups", in Heike Krieger (ed.), Inducing Compliance with International Humanitarian Law: Lessons from the African Great Lakes Region, Cambridge University Press, Cambridge, 2015, pp. 496-499; Laura Înigo Álvarez, Towards a Regime of Responsibility of Armed Groups in International Law, Intersentia, Cambridge/Antwerp/Chicago, 2020, pp. 3, 181-182 and 216-217.

22 See for instance UNSC Res. 2277, 30 March 2016 ("Strongly condemns all armed groups operating in the region and their violations of international humanitarian law"); UNSC Res. 2293, 23 June 2016; Report of the Independent International Fact-Finding Mission on Myanmar, UN Doc. A/HRC/39/64, 12 September 2018, paras 54 and 66; Report of the Independent International Commission of Inquiry on the Syrian Arab Republic, UN Doc. A/HRC/44/61, 2 July 2020, VI. L. Zegveld, above note 20, pp. 223-224; L. Íñigo Álvarez, above note 21, pp. 35-36.

23 Katharine Fortin, "Armed Groups and Procedural Accountability: A Roadmap for Further Thought", in Terry D. Gill, Tim McCormack, Robin Geis, Heike Krieger and Christophe Paulussen (eds), Yearbook of International Humanitarian Law, Vol. 19, T.M.C. Asser Press, The Hague, 2016, p. 159; Agata Kleczkowska, "Filling the Gap: The New Regime of Responsibility for Armed Non-State Actors", Australian International Law Journal, Vol. 25, No. 1, 2018, pp. 150-151.

24 ARS, above note 7, Art. 10.

25 PCIJ, Factory at Chorzów (Germany v. Poland), Series A, No. 9, Judgment (Jurisdiction), 26 July 1927, p. 21; PCIJ, Factory at Chorzów Case (Merits), above note 7, p. 29. 
for the injury caused by their internationally wrongful acts. ${ }^{26}$ As concluded by Evans, "this illustrates a major lacuna in international humanitarian law". ${ }^{27}$ More specifically, it gives rise to a problematic responsibility gap, which manifests itself, at the theoretical level, in terms of the asymmetry that exists between the primary and secondary rules applicable to non-State armed groups, and, in practice, because of the de facto impunity for certain violations of international law. ${ }^{28}$

However, important support for armed groups' possible duty of reparation can be found in the UN Basic Principles, which, as a key international soft law instrument for reparations, has been referred to as "an international bill of rights of victims". ${ }^{29}$ Besides recognizing a State's international obligation of reparation, principle 15 holds:

[i]n cases where a person, a legal person, or other entity is found liable for reparation to a victim, such a party should provide reparation to the victim or compensate the State if the State has already provided reparation to the victim.

Hence, the principle explicitly acknowledges that entities of a non-State nature could be obliged to provide reparations for serious violations of international humanitarian law: this could arguably include non-State armed groups. ${ }^{30}$

This preliminary conclusion finds support in Special Rapporteur van Boven's reflections on the process of discussions and negotiations of the Basic Principles, in which he identified the question of non-State actors as one of the main issues that came up. ${ }^{31} \mathrm{He}$ reveals that there was general support for obligating armed groups, which exercise effective control over a certain territory and people, to make reparation on the basis of "legal liability". ${ }^{32}$ However, the Basic Principles' scope was only extended in a "modest and cautious way", which indicates the drafters' hesitance to make any conclusive decision on the matter. ${ }^{33}$ The latter consideration is also reflected in the adopted term "should", in principle 15, which was used where an international norm was deemed to be

26 ARS, above note 7, Art. 31; J. Henckaerts and L. Doswald-Beck, above note 18, Rules 149 and 150.

27 C. Evans, above note 5, p. 31.

28 V. Bílková, above note 21, p. 275.

29 M. C. Bassiouni, above note 6, p. 203.

30 Andrew Clapham, Human Rights Obligations of Non-State Actors, Oxford University Press, Oxford, 2006, p. 73; Luke Moffett, "Beyond Attribution: Responsibility of Armed Non-State Actors for Reparations in Northern Ireland, Colombia and Uganda", in Noemi Gal-Or, Cedric Ryngaert and Math Noortmann (eds), Responsibilities of the Non-State Actor in Armed Conflict and the Market Place, Brill Nijhof, Leiden/Boston, 2015, p. 331; Paloma Blázquez Rodríguez, "Does an Armed Group Have an Obligation to Provide Reparations to Its Victims? Construing an Obligation to Provide Reparations for Violations of International Humanitarian Law", in James Summers and Alex Gough (eds), Non-State Actors and International Obligations, Brill Nijhof, Leiden/Boston, 2018, p. 409.

31 Theo van Boven, The United Nations Basic Principles and Guidelines on the Right to a Remedy and Reparation for Victims of Gross Violations of International Human Rights Law and Serious Violations of International Humanitarian Law, available at: https://legal.un.org/avl/pdf/ha/ga_60-147/ga_60-147_e. pdf, pp. 1 and 3.

32 Ibid., p. 3.

33 Ibid. 
"less mandatory". ${ }^{34}$ Despite the drafters' attention to non-State armed groups, the final text does not make this focus explicit. This can be explained by the instrument's emphasis on the situation of the victims, regardless of the State or non-State identity of the perpetrator. ${ }^{35}$

Accordingly, principle 15 reflects an "emerging concept of the responsibility" of armed groups under international humanitarian law. ${ }^{36}$ The principle recognizes that these groups could potentially be liable to provide reparations. The significance of this conclusion is reinforced by the status of the Basic Principles, which were adopted by the UN General Assembly without a vote. As pointed out by the International Law Commission, such resolutions carry significant weight and "offer important evidence of the collective opinion of its Members" for the identification of a rule of customary international law. ${ }^{37}$

Nevertheless, there exists little practice on the issue. ${ }^{38}$ Even so, compelling, and recent, practice can be found in Colombia, where the 2016 peace agreement between the government and the Revolutionary Armed Forces of Colombia-People's Army (Fuerzas Armadas Revolucionarias de Colombia-Ejército del Pueblo; FARC-EP) ascribes a role to the non-State armed group in the reparations process on the basis of the group's responsibility for at least breaches of international humanitarian law. ${ }^{39}$ More concretely, the agreement states that "the FARC-EP as insurgent organization that acted in the framework of rebellion, undertakes to contribute to the material reparation of the victims and in general to their comprehensive reparation". ${ }^{40}$ Indeed, the FARC-EP has acknowledged collective responsibility and has offered public apologies on behalf of the group, among other measures. ${ }^{41}$ It builds on a

34 The Right to a Remedy and Reparation for Victims of Violations of International Human Rights and Humanitarian Law - Note by the High Commissioner for Human Rights, UN Doc. E/CN.4/2003/63, 27 December 2002, para. 8.

35 Basic Principles, para. 3(c); Note by the High Commissioner for Human Rights, above note 34, Annex I, para. 114; Marten Zwanenburg, "The Van Boven/Bassiouni Principles: An Appraisal”, Netherlands Quarterly of Human Rights, Vol. 24, No. 4, 2006, pp. 646 and 650-652.

36 As observed by the Chairperson-Rapporteur: "[t]he Principles and Guidelines have been built on international law and practice as they have evolved in the course of the development of the Principles; thus, the emerging concept of the responsibility of non-State actors is reflected in the Principles and Guidelines." The Right to a Remedy and Reparation for Victims of Violations of International Human Rights and Humanitarian Law - Note by the High Commissioner for Human Rights, UN Doc. E/CN.4/ 2004/57, 10 November 2003, para. 13.

37 The General Assembly is a plenary organ of the UN with virtually universal participation. ILC, Draft Conclusions on Identification of Customary International Law, with Commentaries, UN Doc. A/73/10, 2018, Commentary to Draft Conclusion 12, para. 2.

38 As concluded, in different instances, non-State armed groups' international responsibility very much constitutes "a textbook case", or reparations were "rarely asked from armed groups and even more rarely awarded to their victims". M. Sassòli, above note 20, p. 47; International Law Association Committee on Non-State Actors, Washington Conference: Non State Actors, 2014, p. 11.

39 Acuerdo Final para la Terminación del Conflicto y la Construcción de una Paz Estable y Duradera, 24 November 2016, pp. 127-128.

40 Ibid., p. 186 (author's translation).

41 Ibid., p. 178; Sally Palomino, "Las FARC piden perdón en Bojayá por su peor masacre", El País, 9 December 2015, available at: https://elpais.com/internacional/2015/12/08/colombia/1449531312 778130.html; "Farc piden perdón por el atentado contra el club El Nogal en Bogotá", El País, 13 February 2018, available at: https://www.elpais.com.co/proceso-de-paz/farc-piden-perdon-por-elatentado-contra-el-club-el-nogal-en-bogota.html. 
previously established transitional justice process that is regulated by the Justice and Peace Law of 2005, which is said to represent "the ability of armed groups to be held responsible for reparations". ${ }^{42}$ Further support can be found in several peace and other types of agreements concluded between States and armed groups in other countries, such as the Philippines and Sudan. ${ }^{43}$ This latter agreement between the Government of Sudan and the Justice and Equality Movement-Sudan provides that "[t]he Parties shall expeditiously take measures to commence the payment of compensation to returning IDPs [internally displaced persons], refugees as well as all other victims of the conflict". ${ }^{4}$ Moreover, other armed groups have included measures akin to reparations in their own codes of conduct. ${ }^{45}$ Together, these instances of practice contribute to laying the initial foundations for a duty of armed groups to make reparation in cases of humanitarian law violations. ${ }^{46}$

Besides these contemporary examples, important historical precedent can be found in the laws of insurgency and belligerency. Indeed, aspects of State practice, from separated periods, demonstrate that these legal frameworks did not exclude the possibility for States to claim reparations directly from armed groups, especially those exercising control over territory beyond the influence of the State concerned. Concrete examples of such practice can be found in the Spanish Civil War, which was not recognized as a situation of belligerency, and the American Civil War, among other instances. ${ }^{47}$ Fortin's analysis of this practice demonstrates that "the responsibilities that an armed group accrued by virtue of its control of territory were not dependent on a declaration of belligerency per se. ... during the Spanish Civil War, Franco insurgents were regularly held bound by third States to provide compensation for damages that they suffered to persons or

42 Justice and Peace Law of Colombia (Law 975 of 2005); L. Moffett, above note 30, p. 343. Judgment C-370/ 06 of the Constitutional Court introduced the notion of "solidarity civil responsibility" of armed groups into the Justice and Peace Law process. See Constitutional Court of Colombia, Case No. C-370/06, Judgment, 18 May 2006, para. 6.2.4.4 (author's translation).

43 Agreement on Peace between the Government of the Republic of the Philippines and the Moro Islamic Liberation Front, 22 June 2001, Section B, paras 2-3.

44 Agreement between the Government of Sudan and the Justice and Equality Movement-Sudan on the Basis of the Doha Document for Peace in Darfur, 6 April 2013, Art. 17, para. 43.

45 The "Basic Rules" of the New People's Army (NPA) active in the Philippines include as one of their "Eight Points of Attention": "compensate all damages". Similarly, the "Eight Codes of Conduct", which governed the interactions of Revolutionary United Front (RUF) fighters with civilians in Sierra Leone provided that members "pay for everything that you demand or damage". Finally, the National Liberation Army (ELN) Code of War states that "[e]fforts shall be made ... to make reparations where possible". For the primary sources, see Olivier Bangerter, "A Collection of Codes of Conduct Issued by Armed Groups", International Review of the Red Cross, Vol. 93, No. 882, 2011, pp. 489-490 and 497; Geneva Call, Their Words: Directory of Armed Non-State Actor Humanitarian Commitments, available at: http:// theirwords.org/.

46 K. Schmalenbach, above note 21, p. 502.

47 See for examples Charles Rousseau, "La Non-Intervention en Espagne", Revue de droit international et de législation comparée, Vol. 19, No. 2, 1938, pp. 273-274 and 278-280; Roberto Ago, Special Rapporteur, "Fourth Report on State Responsibility", Yearbook of the International Law Commission, Vol. II, 1972, p. 139, para. 181. The latter report refers, as "by far the most important cases", to several formal requests for reparation addressed to the Nationalist authorities by the British Government during the Spanish Civil War, among other examples. 
assets". ${ }^{48}$ Yet, for armed groups lacking territorial control, no similar support in State practice has been identified. ${ }^{49}$

More recent evidence can be found in international practice. Although not a consistent element in its reports, the Independent International Commission of Inquiry on the Syrian Arab Republic recommended, in 2013, that armed groups should provide "effective redress for victims based on international standards". 50 A similar call can be found in the 2005 report of the International Commission of Inquiry on Darfur. ${ }^{51}$ Moreover, certain UN special rapporteurs recently recognized that armed groups should provide reparations for their internationally wrongful acts. ${ }^{52}$ Also some truth commissions recommended that non-State armed groups might contribute in certain ways to reparations. ${ }^{53}$ The Commission on the Truth for El Salvador most clearly recognized a duty to provide reparations, material and moral, by the armed group concerned "where it is found to have been responsible". 54

Overall, the discussion has indicated that the existence of a possible duty of non-State armed groups to provide reparation for violations of international humanitarian law remains characterized by uncertainty: it presents itself as being, predominantly, a matter of lex ferenda. At the same time, the issue is considered as being at an incipient stage in current international law. This conclusion acknowledges that there is at least some legal precedent and recognition that armed groups, particularly with control over territory, should provide reparations when violating their primary obligations in situations of armed conflict. However, it is simultaneously cognisant of the present lack of an established secondary norm of international law to that end and the need for further clarification. In moving beyond this present state of play, and responding to this need, the remainder of the article will explore how a future duty of reparations by nonState armed groups could be operationalized. This process involves examining how such a duty could be conceptualized and put into practice.

48 Katharine Fortin, The Accountability of Armed Groups under Human Rights Law, Oxford University Press, Oxford, 2017, p. 156. See also Jochen Frowein, Das de Facto-Regime Im Völkerrecht, Carl Heymanns Verlag KG, Cologne/Berlin, 1968, p. 84.

49 Sten Verhoeven, "International Responsibility of Armed Opposition Groups: Lessons from State Responsibility for Actions of Armed Opposition Groups", in Noemi Gal-Or, Cedric Ryngaert and Math Noortmann (eds), Responsibilities of the Non-State Actor in Armed Conflict and the Market Place, Brill Nijhof, Leiden/Boston, 2015, p. 297.

50 Report of the Independent International Commission of Inquiry on the Syrian Arab Republic, UN Doc. A/HRC/22/59, 5 February 2013, para. 177(d).

51 Report of the International Commission of Inquiry on Darfur, above note 20, paras 175 and 600.

52 Report on the Protection of the Right to Life, above note 16, para. 94; Report of the Special Rapporteur on the Promotion of Truth, Justice, Reparation and Guarantees of Non-Recurrence, UN Doc. A/HRC/42/45, 11 July 2019, para. 95.

53 Guatemalan Commission for Historical Clarification, Memory of Silence: Conclusions and Recommendations, 1999, p. 49 para. 3 and p. 52 para. 23; Sierra Leone Truth and Reconciliation Commission, Witness to Truth, Vol. 2, 2004, Ch. 3, p. 183 paras 429-432 and p. 199 para. 518.

54 Commission on the Truth for El Salvador, From Madness to Hope: The 12-Year War in El Salvador, UN Doc. S/25500, 1 April 1993, p. 185. 


\section{Operationalizing a duty of non-State armed groups to provide reparations: A multi-faceted proposal}

\section{The law of State responsibility as a point of departure}

As a first step, the methodology which is to frame the analysis needs to be determined. It sets the approach for examining how the reparation rules and principles, which could comprise a future regime of international responsibility of non-State armed groups, could be operationalized. An evident point of departure is the law of State responsibility, which has been referred to as "the paradigm form of responsibility on the international plane". ${ }^{55}$ Indeed, several scholars have relied on this regime as a useful opening to explore the international responsibility of armed groups: by way of analogical legal reasoning. ${ }^{56}$ Although this kind of technique can be useful for filling legal gaps, it should not be understood as a process of mechanically copying and pasting legal rules and principles. The use of analogies instead constitutes a method of legal reasoning based on an assessment of relevant similarities and differences. ${ }^{57}$

Certain similarities between non-State armed groups and States can be noted, which suggest that the rules on State responsibility can constitute an advantageous baseline. Both are collectivities with at least a minimum level of organization, which allows them to engage as distinct entities in organized armed violence of a degree of intensity that reaches the threshold of a noninternational armed conflict. ${ }^{58}$ Some armed groups control territory, in which they may even exercise government functions akin to those of States. ${ }^{59}$ Moreover, armed groups are bound by the same primary obligations as States under international humanitarian law applicable in non-international armed conflict. ${ }^{60}$

However, while some non-State armed groups may display State-like features and could potentially be bound by similar secondary rules as States, others are characterized by their loose organizational structures, absence of any

55 James Crawford and Simon Olleson, "The Character and Forms of International Responsibility", in Malcolm Evans (ed.), International Law, 4th ed., Oxford University Press, Oxford, 2014, p. 444.

56 For example S. Verhoeven, above note 49; Ezequil Heffes and Brian Frenkel, "The International Responsibility of Non-State Armed Groups: In Search of the Applicable Rules", Goettingen Journal of International Law, Vol. 8, No. 1, 2017, pp. 60-65; L. Íñigo Álvarez, above note 21, p. 90.

57 As explained by Ahlborn, the use of analogical reasoning generally involves the application of a legal rule covering a specific case to a different case that is unregulated by law but has similar characteristics. Christiane Ahlborn, "The Use of Analogies in Drafting the Articles on the Responsibility of International Organizations an Appraisal of the 'Copy-Paste Approach", International Organizations Law Review, Vol. 9, No. 1, 2012, pp. 55-57; L. Î́nigo Álvarez, above note 21, pp. 81-83.

58 International Criminal Tribunal for the former Yugoslavia, Prosecutor v. Tadić, Case No. IT-94-1-T, Judgment (Trial Chamber), 7 May 1997, paras 561-562.

59 J. K. Kleffner, above note 21, p. 260. See e.g. Report of the Secretary-General's Panel of Experts on Accountability in Sri Lanka, above note 20, para. 33; Geneva Call, Administration of Justice by Armed Non-State Actors, Geneva, August 2018, p. 5.

60 Sandesh Sivakumaran, The Law of Non-International Armed Conflict, Oxford University Press, Oxford, 2012, pp. 242-243; L. İ̃nigo Álvarez, above note 21, pp. 84-85. 
territorial control, and limited or lack of resources. ${ }^{61}$ With regard to reparations, these observations present themselves as a challenge in terms of the varying degrees of armed groups' capacity to provide reparations: a key issue to be further examined in the next section. For now, it suffices to preliminarily conclude that there is a need to take account of these disparities that exist between armed groups and States, as well as amongst armed groups themselves, when elaborating a future system of responsibility. ${ }^{62}$

Thus, an exercise of analogical reasoning should respond to the particularities presented by armed groups. This process will need to consider that "subjects of law ... are not necessarily identical in their nature or in the extent of their rights", ${ }^{63}$ and will potentially require the development of sui generis rules. ${ }^{64}$ Consequently, it may very well be that different rules govern the international responsibility of distinct subjects. ${ }^{65}$ Even so, the proposed methodology keeps the balance between facilitating a more consistent approach to responsibility in the international legal system and, at the same time, giving consideration to armed groups' specific capacities. ${ }^{66}$

Correspondingly, the rules and principles on reparations included within the law of State responsibility will be used as an initial starting point to frame a possible duty to repair of armed groups. In addition, it is deemed beneficial to consider the existing approaches to reparations in respect of other non-State actors, particularly international organizations and individuals, as a supplementary source of analysis.

\section{The feasibility of holding non-State armed groups to reparations}

Before examining the analogical application of the existing reparation standards under international law to non-State armed groups, it is necessary to better understand the particularities that characterize these groups and, particularly, those that are of specific importance to the question of reparation.

61 Annyssa Bellal, "Establishing the Direct Responsibility of Non-State Armed Groups for Violations of International Norms: Issues of Attribution", in Noemi Gal-Or, Cedric Ryngaert and Math Noortmann (eds), Responsibility of the Non-State Actor in Armed Conflict and the Market Place, Brill Nijhof, Leiden/Boston, 2015, p. 307.

62 J. K. Kleffner, above note 21, p. 261; M. Sassòli, above note 20, p. 47; L. Íñigo Álvarez, above note 21, pp. 67, 85-86 and 90-91.

63 International Court of Justice, Reparation for Injuries Suffered in the Service of the United Nations, Advisory Opinion, ICJ Reports 1949, p. 178.

64 V. Bílková, above note 21, pp. 279 and 284.

65 A similar approach guided the ILC in its work on the responsibility of international organizations. While the Articles on State Responsibility were taken as the general model of international responsibility, it did not imply a general presumption that the same principles apply. Instead, each principle was considered from the specific perspective of the responsibility of international organizations, by taking account of their internal diversity and their differences in comparison with States, amongst other issues. ILC Commentary to the ARIO, above note 7, pp. 46-47, paras 3-7.

66 Alain Pellet, "International Organizations Are Definitely Not States. Cursory Remarks on the ILC Articles on the Responsibility of International Organizations", in Maurizio Ragazzi (ed.), Responsibility of International Organizations, Martinus Nijhoff Publishers, Leiden/Boston, 2013, p. 53; L. Înigo Álvarez, above note 21 , p. 91. 
Although some, but certainly not all, armed groups have State-like features, such groups usually do not have the equivalent organizational capacity as States, nor do they typically possess the same amount of resources. ${ }^{67}$ As argued by Moffett, the "state is in the most appropriate position to carry out reparations as it has the capacity, through its institutions, and the resources to provide effective remedies to victims". ${ }^{68}$ Correspondingly, scholars have indicated that armed groups may lack the capacity to provide reparations to those victimized by their internationally wrongful acts. ${ }^{69}$ Atrocities committed by these groups can result in a vast and complex universe of victims, which could easily overwhelm their practical capabilities to make reparation and, consequently, leave claims without any prospect of success. Groups may, for instance, be indigent or lack the monetary resources to even contribute in a significant manner to redress. Such concerns are not surprising and are certainly not new; they have also been voiced in the academic debates on the duty of reparation by other non-State actors, particularly individuals and international organizations. ${ }^{70}$

The capacity of armed groups to provide reparations may also differ significantly across groups. These capabilities necessarily tie in with a specific group's level of organization and resources. Armed groups may "range from hierarchically complex, well-financed armed groups that exercise control over large swathes of territory at one extreme, to minimally organized, poor, and mobile groups at the other". ${ }^{71}$ Moreover, a group's level of organization may fluctuate over the course of time. As indicated by Ĩnigo Álvarez, an armed group can have a more rudimentary organization at the beginning of an armed conflict and become more sophisticated in later years, or vice versa. Still, an armed group must retain a minimum organized structure to be considered a party to a noninternational armed conflict for the purposes of international law. ${ }^{72}$ Additionally, a group's organizational structure may fragmentize, be absorbed into another group or even dissolve. ${ }^{73}$ The unstable and temporary nature of armed groups may render it difficult to bring reparation claims against the very group that is responsible. ${ }^{74}$ Hence, the overall capacity of an armed group to fulfil a duty of

67 S. Verhoeven, above note 49, p. 299; Daragh Murray, Human Rights Obligations of Non-State Armed Groups, Hart Publishing, Oxford, 2016, p. 172.

68 L. Moffett, above note 30, p. 325.

69 Cecily Rose, "An Emerging Norm: The Duty of States to Provide Reparations for Human Rights Violations by Non-State Actors", Hastings International and Comparative Law Review, Vol. 33, No. 2, 2010, pp. 309-310; R. Dudai, above note 14, pp. 785-786; L. Moffett, above note 30, p. 334.

70 Natalia Szablewska, "Non-State Actors and Human Rights in Non-International Armed Conflicts", South African Yearbook of International Law, Vol. 32, No. 1, 2007, p. 356; Octavio Amezcua-Noriega, Reparation Principles under International Law and Their Possible Application by the International Criminal Court: Some Reflections, Briefing Paper No. 1, Essex Transitional Justice Network, Essex, August 2011, p. 8, para. 30; A. Pellet, above note 66, pp. 49-53.

71 ICRC, Strengthening International Humanitarian Law Protecting Persons Deprived of Their Liberty: Concluding Report, Geneva, October 2015, p. 33.

72 L. Î́nigo Âlvarez, above note 21, pp. 87-88.

73 International Law Association Committee on Non-State Actors, above note 38, p. 10; L. Moffett, above note 30, p. 334.

74 J. K. Kleffner, above note 21, p. 265; Zakaria Daboné, Le droit international public relatif aux groupes armés non étatiques, Schulthess, Zürich, 2012, p. 192. 
reparation may vary significantly in comparison with other groups, may shift over time and may even be rendered infeasible in practice.

While the discussion could lead some to conclude that reparations are simply not relevant for armed groups, Dudai convincingly shows, on the basis of examples from practice, that "at least in some cases, and in relation to at least some forms of reparations, it would indeed be feasible to discuss the question of reparations from armed groups". ${ }^{75}$ Hence, instead of disregarding the issue, there is a need to develop an approach which accommodates these differences in organizational capacity amongst armed groups, and in comparison with States, to ensure the effectiveness of a future regime of international responsibility. The challenge is to come to abstract rules on reparations, which can be applied generally and, at the same time, provide sufficient flexibility to respond to these disparities. $^{76}$ Ultimately, the approach should ensure that the normative framework can be applied effectively on the ground, and avoid the creation of legal fictions. ${ }^{77}$

In addition, victims may not only face difficulties in obtaining reparations from armed groups due to their limited or lack of capacity, but they may also be faced with their lack of willingness. ${ }^{78}$ Both issues call for the incorporation of a mechanism in the proposed legal framework that guarantees, to the greatest extent possible, the provision of redress to the victims, where a group lacks capacity or willingness. ${ }^{79}$

\section{Bridging the gap: The need for a cascading regime of responsibility for reparation}

A central element of the concept of reparation is the intrinsic relation that exists between responsibility for internationally wrongful acts and the duty of the responsible actor to provide reparations. ${ }^{80}$ Besides being encapsulated in judicial decisions, this fundamental principle of international law is also found in other international legal sources. ${ }^{81}$ The regime of State responsibility follows this

75 R. Dudai, above note 14, p. 786. Similarly, see L. Moffett, above note 30, p. 345.

76 J. K. Kleffner, above note 21, pp. 258 and 261. Compare with ARIO, above note 7, ILC Commentary to Art. 2, p. 51, para. 15.

77 Antonio Cassese, International Law, 2nd ed., Oxford University Press, Oxford, 2005, pp. 12-13; Salvatore Zappalà, “Can Legality Trump Effectiveness in Today's International Law?”, in Antonio Cassese (ed.), Realizing Utopia: The Future of International Law, Oxford University Press, Oxford, 2012, p. 106; Taki Hiroshi, "Effectiveness", in Rüdiger Wolfrum (ed.), The Max Planck Encyclopedia of Public International Law, Oxford University Press, Oxford, 2013, para. 1. As put by Íñigo Álvarez: "[a]ny potential system of responsibility will need to take into account these structural differences [between armed groups] in order for such a framework to be realistic.” L. Íñigo Álvarez, above note 21, p. 67.

78 R. Dudai, above note 14, p. 786.

79 L. Moffett, above note 30, p. 346.

80 Ibid., p. 324; P. Blázquez Rodríguez, above note 30, pp. 416-417.

81 PCIJ, Factory at Chorzów Case (Merits), above note 7, p. 29; Inter-American Court of Human Rights, El Amparo v. Venezuela, Series C, No. 28, Judgment (Reparations and Costs), 14 September 1996, para. 14; International Court of Justice, Armed Activities on the Territory of the Congo, above note 9, para. 259; African Court on Human and Peoples' Rights, Comparative Study on the Law and Practice of Reparations for Human Rights Violations, September 2019, p. 4. 
understanding, by conceptualizing the obligation of reparation as "the immediate corollary of a State's responsibility" or, in other words, "as an obligation of the responsible State resulting from the breach". ${ }^{22}$ The Articles on the Responsibility of International Organizations reproduce this approach. ${ }^{83}$ The same intrinsic relationship is also reflected in the reparations orders of the International Criminal Court, which are "intrinsically linked to the individual whose criminal liability is established in a conviction". 84

From this discussion, it logically follows that the violator of an international norm, i.e. the responsible actor, should bear the primary duty to provide reparation. Correspondingly, a strong argument can be made that a non-State armed group should bear this primary duty for its own wrongful conduct in international law. Such a proposition should not be deemed controversial, since it follows established principles in international law, as has been previously demonstrated.

That being said, armed groups may lack the organizational capacity to provide reparations, may only be capable of fully or partly contributing to certain forms of reparation, or might simply cease to exist. Others may be unwilling to take up responsibility for remedying the past. Therefore, a future regime of responsibility should not make the provision of reparations to those who suffered injury solely dependent upon such actors.

Similar considerations are reflected within the legal frameworks which govern the duty of reparation by other non-State actors. The Articles on the Responsibility of International Organizations include, for instance, an obligation for the members of a responsible organization to enable it to fulfil its reparation obligation..$^{85}$ Similarly, the reparations scheme of the International Criminal Court assigns a role to the Trust Fund for Victims where the convicted person's resources are insufficient, which has been the case regarding all reparations orders issued thus far. ${ }^{86}$ This reality illustrates that reparations cannot be fully dependent upon non-State perpetrators alone. ${ }^{87}$

In line with the underlying rationale of these approaches, the Basic Principles assign a subsidiary role to the State with a view to mitigating the difficulties that the provision of reparation by a non-State actor may experience.

82 ARS, above note 7, ILC Commentary to Art. 31, p. 91, para. 4.

83 See ARIO, above note 7, Art. 31.

84 ICC, Lubanga, above note 8, para. 20 (emphasis in original).

85 ARIO, above note 7, Art. 40(2); Paolo Palchetti, "Exploring Alternative Routes: The Obligation of Members to Enable the Organization to Make Reparation", in Maurizio Ragazzi (ed.), Responsibility of International Organizations, Martinus Nijhoff Publishers, Leiden/Boston, 2013, pp. 304-305.

86 Rome Statute, above note 7, Art. 75(2); ICC, The Prosecutor v. Thomas Lubanga Dyilo, Case No. ICC-01/ 04-01/06-2904, Decision Establishing the Principles and Procedures to Be Applied to Reparations (Trial Chamber), 7 August 2012, para. 269; ICC, The Prosecutor v. Germain Katanga, Case No. ICC-01/04-01/ 07-3728, Order for Reparations (Trial Chamber), 24 March 2017, para. 327; ICC, The Prosecutor v. Ahmad Al Faqi Al Mahdi, Case No. ICC-01/12-01/15-236, Reparations Order (Trial Chamber), 17 August 2017, para. 113; ICC, The Prosecutor v. Bosco Ntaganda, Case No. ICC-01/04-02/06-2659, Reparations Order (Trial Chamber), 8 March 2021, para. 254; Miriam Cohen, Realizing Reparative Justice for International Crimes: From Theory to Practice, Cambridge University Press, Cambridge, 2020, pp. 138, 141 and $146-147$.

87 A. Pellet, above note 66, pp. 49-50; African Court on Human and Peoples' Rights, above note 81, p. 13. 
Principle 16 holds that "States should endeavour to establish national programmes for reparation and other assistance to victims in the event that the parties liable for the harm suffered are unable or unwilling to meet their obligations." ${ }^{8}$ This scheme ensures that victims have access to redress either way. ${ }^{89} \mathrm{~A}$ similar position has been echoed in other legal instruments, such as the Chicago Principles on Post-Conflict Justice. ${ }^{90}$ Furthermore, this approach to non-State armed groups enjoys support in international practice and legal scholarship. ${ }^{91}$

Building on this scheme, the territorial State could bear a subsidiary responsibility to provide reparations for the wrongful acts of a non-State armed group: as a matter of $\operatorname{law}^{92}$ or, at least, out of a sense of morality, where the responsible group is unable or unwilling. ${ }^{93}$ Yet, it is clear that the character of this form of responsibility would eventually determine the extent to which a State could be legally compelled, where it lacks the political will, to step in. Regardless of this concern, States have in some cases taken on, exclusively or along with the concerned armed group, the provision of reparations to all victims of the respective armed conflict. ${ }^{94}$ The State could carry out this role by, for instance, creating a special trust fund, an administrative reparations programme, or introducing a dedicated line in the annual budget. ${ }^{95}$ This approach reflects the reality within the majority of conflict and post-conflict situations, namely that reparations cannot be provided by perpetrators alone, and thereby, necessitating the application of a comprehensive approach to reparations in order to address the full range of needs. ${ }^{96}$ Additionally, the international community could

88 (Emphasis added).

89 Basic Principles, paras 3(c)-(d), 8 and 11(b); L. Moffett, above note 30, p. 331.

90 International Human Rights Law Institute, The Chicago Principles on Post-Conflict Justice, 2007, principle 3.3.

91 Report of the International Commission of Inquiry on Darfur, above note 20, paras 590-592; L. Moffett, above note 30, p. 335 (he discusses Colombia and Uganda as examples of State practice); Francesca Capone, Reparations for Child Victims of Armed Conflict, Intersentia, Cambridge, 2017, pp. 102-103; P. Blázquez Rodríguez, above note 30, p. 428; Office of the United Nations High Commissioner for Human Rights, Joint Statement by Independent United Nations Human Rights Experts on Human Rights Responsibilities of Armed Non-State Actors, 25 February 2021, available at: https://www.ohchr. org/EN/NewsEvents/Pages/DisplayNews.aspx?NewsID=26797\&LangID=E.

92 It remains unclear, in both practice and legal scholarship, whether a State should substitute, as a matter of law, an armed group's possible duty to repair. Annyssa Bellal, "Non-State Armed Groups in Transitional Justice Processes: Adapting to New Realities of Conflict", in Roger Duthie and Paul Seils (eds), Justice Mosaics: How Context Shapes Transitional Justice in Fractured Societies, International Center for Transitional Justice, New York, 2017, p. 243.

93 L. Magarrell, above note 13, pp. 10-11.

94 See Comprehensive Agreement on Human Rights (Guatemala), 29 March 1994, VIII; Peace Agreement between the Government of Sierra Leone and the Revolutionary United Front of Sierra Leone (Lomé Peace Agreement), 7 July 1999, XXIX; Mark Freeman and Iván Orozco, Negotiating Transitional Justice: Firsthand Lessons from Colombia and Beyond, Cambridge University Press, Cambridge, 2020, pp. 153-154.

95 Basic Principles, para. 16; Office of the United Nations High Commissioner for Human Rights, Rule-ofLaw Tools for Post-Conflict States: Reparation Programmes, New York/Geneva, 2008, p. 32; Report of the Panel of Experts on Accountability in Sri Lanka, above note 20, p. 122.

96 Examples can be found in the approaches to reparations for victims of the Colombian armed conflict within the context of Law No. 1448 of 2011, see Luke Moffett, Cheryl Lawther, Kieran McEvoy, Clara Sandoval and Peter Dixon, Alternative Sanctions Before The Special Jurisdiction For Peace: Reflections 
provide further assistance in particularly weak and resource-scarce States through, for instance, an international trust fund for victims. ${ }^{97}$ The redress offered by third actors must be accompanied by an acknowledgment of victimhood in order to ensure its reparative nature and to distinguish it from humanitarian assistance, development or similar initiatives..$^{98}$

From these considerations emerges a proposal for a cascading regime of responsibility for reparation: the responsible armed group bears the principal duty to provide reparation; the territorial State incurs a subsidiary responsibility, to the extent that the group is unable or unwilling; and the international community takes a potential additional role. In practice, the State may end up taking a complementary role in the provision of reparations, where the responsibility of the armed group is only partially exercised. As will be further elaborated on in the next section, this might be the case when a group has the capacity to contribute to the provision of reparations, but cannot do so fully. The main objective of this cascading regime is to guarantee, to the greatest extent possible, the required redress for victims.

\section{Reparations from non-State armed groups: A way forward}

The adequate forms of reparation required in a given case are usually determined on the basis of the nature of the violation and the resulting harm that was caused, which consequently frame the duty to provide reparation. ${ }^{99}$ This framing exercise does not take the type of responsible entity into consideration. ${ }^{100}$ Although the rules on State responsibility do allow some flexibility in how full reparation is to be achieved, by introducing elements of equity and reasonableness, this does not go as far as granting the possibility of restricting the quantum or quality of reparation owed when it merely proves to be difficult for the wrongdoer to comply. ${ }^{101}$

on International Law and Transitional Justice, 2019, para. 141; Nelson Camilo Sanchez and Adriana Rudling, Reparations in Colombia: Where To?, Policy Paper, 2019, pp. 29 and 31.

97 The UN Special Rapporteur on extrajudicial, summary or arbitrary executions suggested that an option is for the international community to step in. It was recommended to States, under the auspices of the UN or other international process, to established trust funds to ensure reparations for victims of armed groups. Report on the Protection of the Right to Life, above note 16, paras 92 and 100(a).

98 Heidi Rombouts, Pietro Sardaro and Stef Vandeginste, "The Right to Reparation for Victims of Gross and Systematic Violations of Human Rights", in Koen de Feyter, Stephan Parmentier, Marc Bossuyt and Paul Lemmens (eds), Out of the Ashes: Reparation for Victims of Gross and Systematic Human Rights Violations, Intersentia, Antwerp/Oxford, 2005, p. 466.

99 International Court of Justice, Avena and Other Mexican Nationals (Mexico v. United States of America), Judgment, ICJ Reports 2004, para. 119; Note by the Secretary-General, above note 11, para 31; African Court on Human and Peoples' Rights, above note 81, p. 2.

100 Carla Ferstman, International Organizations and the Fight for Accountability, Oxford University Press, Oxford, 2017, pp. 68 and 84.

101 Ibid., p. 90. See ARS, above note 7, ILC Commentary to Art. 34, p. 96, para. 5. The ILC argued in a similar manner regarding international organizations: "[i]t may be difficult for an international organization to have all the necessary means for making the required reparation ... that inadequacy cannot exempt a responsible organization from the legal consequences resulting from its responsibility under international law." ARIO, above note 7, ILC Commentary to Art. 31, p. 77, para. 4. 
These practices are taken as the starting point in respect of reparations from non-State armed groups. However, a proposal is made to still take account of a responsible group's organizational capacity to deliver the required forms of redress when concretely applying the duty of reparation to that group, whilst safeguarding the reparation that is owed through a subsidiary mechanism.

Although this proposal is not mirrored in the law of State responsibility, it finds support in the current regulation of armed groups under the primary rules of international humanitarian law. Indeed, the process of determining the scope of primary obligations applicable to a particular armed group is not done in an abstract manner. Instead, it includes an evaluation of that group's level of organization to ensure its normative capacity. More concretely, a greater body of obligations will bind an armed group under Additional Protocol II, which requires a higher degree of organization of that group, compared with an armed group with a minimum level of organization, sufficient for the sole application of common Article 3. As explained in the Boškoski case:

[t]his difference in the required degree of organisation is logical in view of the more detailed rules of international humanitarian law that apply in Additional Protocol II conflicts ... By contrast, Common Article 3 reflects basic humanitarian protections, and a party to an armed conflict only needs a minimal degree of organisation to ensure their application. ${ }^{102}$

Thus, as observed by Sivakumaran, there is "a close nexus between the organization of the armed group and the content of the applicable law". ${ }^{103}$ This reasoning finds support in the text of article 1(1) of Additional Protocol II, which holds that armed groups should be under responsible command and in control over territory "as to enable them ... to implement this Protocol". The ICRC Commentary recognizes that the higher threshold for application has a "degree of realism". ${ }^{104}$ The Commentary submits that in such circumstances it can be reasonably expected that the parties apply "the rules developed in the Protocol" given they have "the minimum infrastructure required therefor". ${ }^{105}$

The discussion shows that an armed group's level of organization is used as an indicator of its normative capacity to apply the imposed obligations under international humanitarian law. This results in a differentiated approach to the legal regulation of armed groups in terms of their primary obligations. ${ }^{106}$ Fundamentally, the international legal framework shows sensitivity towards ensuring the reasonable feasibility of a group to fulfil its obligations. In doing so,

102 International Criminal Tribunal for the Former Yugoslavia, Prosecutor v. Boškoski and Tarčulovski, Case No. IT-04-82-T, Judgment (Trial Chamber), 10 July 2008, para. 197.

103 S. Sivakumaran, above note 60, p. 185. Similarly Marco Sassòli, International Humanitarian Law, Edward Elgar Publishing Limited, Cheltenham, 2019, para. 10.232.

104 Yves Sandoz, Christophe Swinarski and Bruno Zimmermann (eds), Commentary on the Additional Protocols, ICRC, Geneva, 1987, para. 4470.

105 Ibid.

106 K. Fortin, above note 48, pp. 134-136 and 152-153; Tilman Rodenhäuser, Organizing Rebellion, Oxford University Press, Oxford, 2018, pp. 12-13. 
it legally responds to the challenges posed by the heterogeneous nature of armed groups, while rending the regulatory regime more realistic. ${ }^{107}$

A similar differentiated approach could inform the operationalization of the possible obligations that arise for armed groups under the secondary rules of international law, particularly vis-à-vis reparations. This has the potential to be a viable solution to the capacity concerns which have been previously addressed. There is no apparent reason why these considerations could not be extended to the sphere of international responsibility.

\section{Moving towards an actor-specific approach}

Building on these findings, a proposal is made for an actor-specific approach to the application of a duty of reparation to an armed group in a given case. This entails that a case-specific evaluation is made of the level of organization and resources of a responsible group, as indicators of its organizational capacity to comply with the imposed duty. The objective of this evaluation is to determine the concrete scope of the group's duty of reparation, by considering two interrelated aspects.

The first aspect concerns the range of reparation forms which have been requested from the responsible armed group in an effort to accomplish restitutio in integrum. Under the proposed approach, an evaluation would help determine which of these forms of reparation the group could actually provide for. For instance, an armed group, which holds a limited degree of organization and hardly any resources, may have been requested to provide satisfaction and monetary compensation. However, an evaluation made under the actor-specific approach might reveal that, due to its lack of capacity, the group is unable to provide for both. As such, the actor might be primarily obliged to provide the ordered measures of satisfaction, as their provision is within the group's capabilities. Yet, as will be demonstrated, this approach is contingent on the State stepping in to ensure full reparation.

The second aspect concerns the conduct which is required to deliver a particular form of reparation or, indeed, full reparation. In this regard, when an armed group is not capable of fully satisfying the reparation ordered against it, the group could be required to contribute to, or at least facilitate, the provision of reparation by States or other actors. Mégret makes a similar argument with regard to symbolic reparations and guarantees of non-repetition afforded by responsible individuals. While certain forms of symbolic reparation may be beyond their capacity, individuals could still help in bringing such reparation to fruition. For example, although individuals might not be ordered to search for the whereabouts of the disappeared altogether, they could still assist in that process by sharing information on the matter. ${ }^{108}$ 
Such reasoning is deemed equally relevant for non-State armed groups. Similarly, a responsible armed group may not be capable of providing rehabilitative services to victims residing under its control, but the group could at least facilitate the delivery of such services by other actors through the granting of access to these areas of the territory. ${ }^{109}$ A group could also contribute to providing satisfaction to victims by at least disclosing information on certain violations, which could be instrumental in a truth-seeking process. ${ }^{110}$ Finally, if resources are limited, they can still be used to contribute, even symbolically, to compensation, or the financing of other forms of reparation through, for instance, a State-led fund or reparations programme. ${ }^{111}$

The majority of armed groups could probably provide certain reparation forms in international law with more ease than others. It is likely that, for instance, restitution by way of the return of wrongly seized property or satisfaction through public apology commonly require a lesser degree of organizational capacity than rehabilitation services and monetary compensation. Nonetheless, the discussion demonstrates that poorly organized armed groups could still be able to contribute to, or at least facilitate, the provision of these latter measures of reparation.

At the same time, the approach leaves room for the development of adjusted or new reparation forms, which could accommodate the specific capabilities of armed groups, by capitalizing on their collective efforts, skills and knowledge in certain areas. ${ }^{12}$ Indeed, such examples can be found in Colombia, where the FARC-EP has engaged in concrete actions, such as infrastructurerebuilding work in conflict-affected areas or humanitarian demining, with a view of contributing to reparation. ${ }^{113}$ However, any attempt to think outside the box needs to carefully guard the concept of reparation. This legal concept should not

109 Basic Principles, para. 21; Jann K. Kleffner and Liesbeth Zegveld, "Establishing an Individual Complaints Procedure for Violations of International Humanitarian Law", in Yearbook of International Humanitarian Law, Vol. 3, 2000, p. 400. A practical example can be found in Geneva Call, Deed of Commitment for the Prohibition of Sexual Violence in Situations of Armed Conflict and Towards the Elimination of Gender Discrimination, available at: https:/www.genevacall.org/wp-content/uploads/ 2019/07/DoC-Prohibiting-sexual-violence-and-gender-discrimination.pdf, para. 4.

110 Basic Principles, para. 22(b); Lars Waldorf, "Ex-Combatants and Truth Commissions", in Ana Cutter Patel, Pablo de Greiff and Lars Waldorf (eds), Disarming the Past: Transitional Justice and Excombatants, Social Science Research Council, New York, 2009, pp. 120-121; Luke Moffett, Cheryl Lawther, Kieran McEvoy, Clara Sandoval and Peter Dixon, above note 96, paras 130 and 132. Recent examples can be found in the Colombian context, see Carolina Ávila, "La comisión de Farc que busca a los desaparecidos", El Espectador, 12 March 2019, available at: https://www.elespectador.com/ colombia-20/jep-y-desaparecidos/la-comision-de-farc-que-busca-a-los-desaparecidos-article/.

111 See for concrete examples Law No. 1448 of 2011 (Colombia), Art. 177(a); Sierra Leone Truth and Reconciliation Commission, above note 53, p. 183; Note by the Secretary-General, above note 11, para. 57(b).

112 Correspondingly, the Basic Principles contain a non-exhaustive list of reparation forms, which allows for other forms that might be more appropriate in a concrete case. M. Zwanenburg, above note 35, p. 666.

113 Acuerdo Final para la Terminación del Conflicto y la Construcción de una Paz Estable y Duradera, above note 39, pp. 178-179; Kroc Institute for International Peace Studies, Segundo Informe sobre el Estado Efectivo de Implementación del Acuerdo de Paz en Colombia diciembre 2016-mayo 2018, 2018, p. 211; Andrés Bermúdez Liévano, "Will Colombia's FARC be Allowed to Clear Mines to Repair their Victims?", JusticeInfo.net, 2 March 2020, available at: https://www.justiceinfo.net/en/43929-willcolombia-farc-be-allowed-to-clear-mines-to-repair-their-victims.html. 
be stretched to any action that contributes to some form of development. Otherwise, it risks being robbed of its specificity and significance.

All in all, the proposed approach takes account of armed groups' varying capabilities and thus results in a differentiated and case-sensitive application of the duty to repair to such groups. Yet, as briefly raised, the viability of this actorspecific approach proposal is dependent on a crucial condition: the various forms of reparation ordered, so as to secure full reparation, are to be guaranteed by the subsidiary responsibility of the territorial State. In this conception, the State would be prompted to contribute to the extent that the responsible armed group lacks capacity. The well-established principle of full reparation would thus be upheld, insofar possible regarding gross violations, by way of a division of responsibility between the armed group and the State. ${ }^{114}$ Here, the actor-specific approach ties in with the cascading regime of responsibility for reparation, as presented in the previous section. At the same time, the provision of certain forms of reparation, such as public apologies, cannot be substituted by the State. As such, the role of the responsible group could prove to be indispensable. ${ }^{115}$

The justification for the proposed approach lies in the need to develop a realistic normative framework, that reasonably ensures the effectiveness of the reparation obligations imposed upon a non-State armed group. As previously argued, this requires accommodating concerns over divergent capabilities of an armed group, in comparison with States and other groups. Similar to the primary rules of international humanitarian law, the proposed approach, based on organizational capacity, allows for a matching of the international legal framework with realities on the ground. It thereby responds to such concerns.

The notion that an armed group's organizational capacity determines the extent to which it is concretely bound to provide reparation raises the question as to which indicia could be used to evaluate such capacity in a given case. The International Criminal Tribunal for the former Yugoslavia has adopted a number of indicative factors to assess the organization of an armed group, as part of the two-fold test to determine the existence of a non-international armed conflict. Some of these could form a useful starting point to develop evaluative indicia. The group of factors which indicates that an armed group is able to speak with one voice could, for example, display a group's capacity to authoritatively provide public apologies or acknowledge collective responsibility. ${ }^{116}$ Similarly, factors which signal the presence of a command structure could be indicators of the ability of a group to implement guarantees of non-repetition among its members, e.g., by issuing and disseminating internal regulations. ${ }^{117}$ Further research is

114 N. Roht-Arriaza, above note 7, p. 158. Similarly, regarding the responsibility of international organizations: "the principle of full reparation is not put in question". See ARIO, above note 7, ILC Commentary to Art. 31, p. 77, para. 3.

115 L. Íñigo Álvarez, above note 21, p. 197.

116 International Criminal Tribunal for the Former Yugoslavia, Boškoski, above note 102, para. 203.

117 Ibid., para. 199. A concrete manifestation can be found in the practice of the UN Security Council, which has called upon parties to armed conflict to make and implement commitments to combat sexual violence, which should include, among other things, the issuance of clear orders through chains of command prohibiting sexual violence. UNSC Res. 1960, 16 December 2010, para. 5. 
needed on the specific forms of reparation and the different organizational capacities that are required for an armed group to provide them. Dudai has, for instance, identified several organizational features, such as internal cohesion, discipline and strong leadership, which he views as being vital factors for the feasibility of an armed group's engagement in measures of truth-recovery and symbolic reparation. ${ }^{118}$ Kleffner and Zegveld have argued, in their turn, that credible rather than illusory reparative measures should be ordered; with regard to monetary compensation, this could entail that the economic position of the armed group is taken into account. ${ }^{119}$

\section{Concluding observations}

In going beyond the uncertainty that surrounds the existence of a duty to provide reparations by non-State armed groups, the article has presented a multi-faceted proposal on how this duty could be operationalized as part of a future regime of international responsibility. This novel proposal responds to the particularities presented by armed groups and aims to bring forward a realistic normative framework which is grounded in existing approaches in international law and practice. Moreover, a future domestic or international forum could apply this framework to judicial or administrative reparations claims directed to armed groups. It can also inform extra-judicial initiatives that address the question of reparations, such as the work of truth commissions and peace negotiations with armed groups.

The article has demonstrated that a possible duty of armed groups to provide reparations for their internationally wrongful acts could be conceptualized in a similar manner to that of States under international law. The main difference lies in how this framework of abstract rules and principles is to be put into practice, or rather, concretely applied to an armed group, by way of the actor-specific approach and the cascading regime of responsibility for reparation.

The proposal to adopt an actor-specific approach to the application of a particular group's duty to make reparation injects flexibility into the regulatory framework, which assists in accommodating the specificities of a given case. This actor-specific approach does not stray away from the existing methods to frame a responsible entity's duty of reparation, nor does it go as far as to argue that the required redress should be restricted when it proves to be difficult for that entity. Instead, the proposed approach involves making a case-specific assessment of the responsible armed group's level of organization and resources, as indicators of its organizational capacity to comply with the obligations arising from its duty of repair. The aim of this assessment is to determine the concrete scope of the 
group's duty: in terms of the reparation forms it is required to grant and the extent of its engagement in the provision of reparatory measures.

The subsidiary responsibility of the territorial State could be subsequently triggered, as part of the proposed cascading regime of responsibility for reparation, to the extent that an armed group lacks the capacity to comply with its duty of reparation. Thus, the approach could result in a division of responsibility between the group and the State. This scheme ultimately seeks to safeguard the full provision of the required redress. The same subsidiary mechanism is activated when a group would be unwilling to provide reparations. Moreover, the international community could serve an important role in providing supplementary assistance. Fundamentally, the proposal is premised on the argument that reparations for victims of armed conflict cannot be solely dependent on non-State armed groups.

This multi-faceted proposal implies that the well-established principle of full reparation, as well as the five main forms of reparations included in the Basic Principles, could be transposed to armed groups by analogy, without too many modifications, but possibly requiring the substitution by the State in practice. ${ }^{120}$ At the same time, adjusted or new forms could be envisaged for armed groups. This conception differs from other authors, who have emphasized certain forms of reparation that supposedly come closer to the objective capabilities of nonState armed groups. ${ }^{121}$

In addition, the proposed approach accommodates all types of armed groups, from highly organized groups which exercise control over a territory, to groups which maintain a minimum level of organization, and thus, not solely groups which resemble States. This inclusive approach differs from the tendency, within international law, to emphasize the international responsibility of groups with territorial control or State-like characteristics. ${ }^{122}$ In doing so, the potential opening of a responsibility gap when a group no longer reaches this standard is prevented. Indeed, as was demonstrated, a group's level of organization is not necessarily stable and may fluctuate over the course of an armed conflict. This reality could bar victims from directly addressing a responsible group where it no longer falls within the law of international responsibility. Instead, following the proposed approach, victims of different types of armed groups are treated equally under international law. Or, differently, all armed groups can be held internationally responsible for their wrongful conduct.

120 Similarly J. K. Kleffner, above note 21, p. 264.

121 See Konstantinos Mastorodimos, Armed Non-State Actors in International Humanitarian and Human Rights Law, Routledge, London/New York, 2016, p. 127; P. Blázquez Rodríguez, above note 30, pp. $417-422$.

122 In addition to the previous references to instances of State practice in situations of belligerency and insurgency as well as to the Basic Principles' drafting process, see ILC Commentary to draft Art. 14 ARS, pp. 91-92 paras 3-4 and pp. 98-99 para. 28, Yearbook of the International Law Commission, Vol. II, 1975; Zakaria Daboné, "International Law: Armed Groups in a State-Centric System", International Review of the Red Cross, Vol. 93, No. 882, 2011, p. 412; Report of the Detailed Findings of the Group of Eminent International and Regional Experts on Yemen, UN Doc. A/HRC/42/CRP.1, 3 September 2019, para. 868 . 
Although the multi-faceted proposal could certainly be applied to a nonState armed group during an ongoing armed conflict, insofar that the responsible group is still an identifiable entity, the matter is that reparations have been usually claimed and provided for after a conflict has ended. ${ }^{123}$ Yet, post-conflict reparations by an armed group constitute a complicated issue, since the group will no longer legally exist in international law. ${ }^{124}$ Nonetheless, the proposal presented in this article implies that victims could still call upon the subsidiary responsibility of the State. It recognizes that reparations by armed groups will not be feasible in all cases. Thus, the cascading regime of responsibility for reparation seeks to provide victims to the extent possible with a final safety net.

123 Jemima García-Godos and Knut Andreas O. Lid, “Transitional Justice and Victims’ Rights before the End of a Conflict: The Unusual Case of Colombia", Journal of Latin American Studies, Vol. 42, No. 3, 2010, pp. 487-488; K. Mastorodimos, above note 121, p. 133.

124 As explained by Zegveld, "The legal personality of armed opposition groups is based on their position as parties to an internal armed conflict.” L. Zegveld, above note 20, p. 152. 